\title{
33
}

\section{Addendum 8: Table of Japan Prize Awards Citing the Laser, 1987-2014}

\begin{tabular}{lll}
\hline Year & Cited achievement & Laureate \\
\hline 1987 & Realization of the first laser & Theodore H. Maiman \\
1995 & $\begin{array}{c}\text { Contributions to research and practical } \\
\text { applications of light emitting diodes } \\
\text { and lasers }\end{array}$ & Nick Holonyak, Jr. \\
1996 & $\begin{array}{c}\text { Research on wideband low-loss optical } \\
\text { fiber communications }\end{array}$ & $\begin{array}{c}\text { Charles K. Kao (also Nobel Prize } \\
\text { in 2009) }\end{array}$ \\
2014 & $\begin{array}{c}\text { Semiconductor lasers for high- } \\
\text { capacity long-distance optical fiber } \\
\text { communication }\end{array}$ & Yasuharu Suematsu \\
\hline
\end{tabular}

Note Bob Kahn and Vint Cerf, creators of the TCP/IP protocols fundamental to the operation of the Internet, were also awarded the Japan Prize in 2008. It is notable that creators of all of the requisites of the modern Internet-lasers, fiber optics, and protocols—have been awarded Japan Prizes 